\title{
Design and implementation of an automatic hydrological monitoring system for hydropow- er plants
}

\author{
Thiết kế, chế tạo hệ thống tụ động giám sát thủy văn cho nhà máy thủy điện \\ Research article
}

Co, Nhu Van ${ }^{1}$; Pham, Huy Duy ${ }^{2}$ Chu, Thi Thu Ha ${ }^{3}$; Ngo, Thanh Binh ${ }^{4}$

${ }^{1}$ Centre of Science and Technology, University of Transport and Communications, Lang Thuong, Dong Da, Hanoi, Vietnam; ${ }^{2}$ Dynamic Solutions International-LLC - Vietnam representative office, Hanoi, Vietnam, ${ }^{3}$ Institute of Ecology and Biological Resources, Vietnam Academy of Science and Technology, 18 Hoang Quoc Viet, Hanoi, Vietnam; ${ }^{4}$ Faculty of Electrical and Electronic Engineering, University of Transport and Communications, Lang Thuong, Dong Da, Hanoi, Vietnam.

\begin{abstract}
Nowadays, the management of parameters measured at the power plants is an urgent requirement for each country. The automatic systems measuring process parameters of hydropower plants as well as water management systems have been applied and flourished in the developed countries. Some important parameters of the hydro plants such as rainfall, level of river, level of water reservoir, flow rate of water in canals and rivers, as well as parameters related to safety dams are measured by sensors, processed suitably and sent to the management centre. In Vietnam and Laos so far most hydropower plants do not have an automatic data monitoring system and most parameters are transmitted manually, which is very time consuming and difficult to implement. Therefore, this paper introduces a new real-time, automatic system to overcome these problems. The design includes features such as automatic collecting, processing and transmitting data to the monitoring and management centre. Besides regulating water resources and capacity of the plant to reach the highest efficiency, the parameters of the system also help to assess impact, manage and monitor the environment. The device was designed, created, and used as visualization tool for teaching purposes in the Faculty of Electrical and Electronic Engineering, University of Transport and Communications in Vietnam, and installed as a technology transfer program in the Theun Hinboun hydropower plant, Na Hin village, Borikhamxai province, Lao People's Democratic Republic.
\end{abstract}

Hiện nay việc quản lý tham số đo đạc tại các nhà máy thủy điện là một yêu cầu cấp bách đối với mồi quốc gia. Các hệ thống tư động hóa đo các tham số của nhà máy thủy điện cung nhu các hê thống quản lý nguồn nước đã được ứng dụng và phát triển mạnh mẽ ở các nước phát triển. Một số tham số quan trọng của nhà máy thủy điện nhu luợng mua, mục nước sông, mưc nuóóc hồ chứa, tốc độ của dòng chảy của nước trên các kênh và trên sông, cũng nhu các tham số liên quan đến độ an toàn của đập, kè bao đều được đo bởi các cảm biến, sau đó được xủ lý một cách phù hợp và được đura về trung tâm quản lý. Tại Việt Nam và Lào cho đến nay hầu hết các nhà máy thủy điện không có hệ thống giám sát dũ liệu tư động và hầu hết các thông số được truyền một cách thủ công rất tốn thời gian và khó khăn để thực hiện. Vì vây, bài viết này giới thiệu một hệ thống mói tư động thời gian thực nhằm khắc phục nhũng vấn đề này. Hệ thống thiết kế có một số tính năng nhu tụ động thu thập, xử lý dĩ liệu và truyền dũ liệu về trung tâm quản lý giám sát. Ngoài việc điều tiết nguồn nuớc cũng nhu công suất của nhà máy sao cho đạt hiệu quả cao nhất, các thông số của hệ thống còn giúp đánh giá tác động và quản lý giám sát môi truơong. Thiết bị đã được thiết kế, chế tạo thành công, được sủ dụng làm công cu trục quan phuc vu giảng dạy tại khoa Điện-Điện tử truờng Đại học Giao thông Vận tải, Việt Nam và được chuyển giao lẳp đặt cho nhà máy thủy điện Theun Hinboun, bản Na Hin thuộc tỉnh Borikhamxai, nuớc Cộng hòa dân chủ nhân dân Lào.

Keywords: automatic monitoring system, hydropower plant, water management 


\section{Introduction}

The measurement of hydrological parameters of hydropower plants is very important for the overall operation efficiency of the plant. From that measurement, the operators of the plant can know the values of important parameters such as rainfall, level of water on river or lake, and parameters related to the safety of dams, embankments. The automatic systems measuring parameters of hydropower plants have been used in a long time in the developed countries. However, in Vietnam as well as in other developing countries, many measurement systems are only semi-automatic rather than fullly automatic. These systems only measure and store the data automatically in their internal memory. Human operators do the collecting and sending of the data to the processing centre manually. To collect the data, workers have to access the areas in order to get the required parameters whereas hydro plants are always located in rough areas nearby rivers, waterfalls, sloping mountains etc. Thus, these works are very laborious, costly, and the parameters are not collected in real time, which makes these semiautomatic systems unsuitable for emergency situations.

Today, with the rapid development of telecommunication groups, mobile phone signal is available in most places in Vietnam. The system combining automatic measurement and automatic transmission of data via GPRS to the control centre is very practical and brings a high economic benefit. In addition, data is sent to the centre in real-time, which enables the executive staff to get real-time information about each area of interest, at any time. By using the measurement results, they can provide early warnings to prevent an expected hazard, as well as provide useful information about the environmental impact of the plant. For example, in China, Han et al., 2012 designed a hydrological monitoring system as an application of ZigBee technology, based on GSM communication.

\section{Location and status}

In Vietnam, the monitoring systems in some hydropower projects do not work effectively. The hydrological monitoring frequency conducted at the power plants such as Ialy plant, Se San 4 plant and Buon Kuop plant is only 23 times/year. Until recently, the Vietnam Environment Agency under the Ministry of Natural Resources and Environment plans to increase the annual number of observations to 3-6 times/year by 2015-2017 (Environmental Monitoring Centre, 2012). Several new small hydropower plants in Vietnam (such as Song Tranh 2) are equipped nowadays with automatic systems for parameters monitoring. The good performance obtained increased the interest in the development of new automatic monitoring systems, with even more features, and encouraged their implementation at transboundary scale. In this paper, we developed an automatic hydrological monitoring system for the Theun Hinboun hydropower plant, which is located in the hydrographic basin of river Theun in Borikhamxai province of Lao People's Democratic Republic. The parameters surveyed are collected from several areas within the river basin (rivers and streams flowing into the reservoir of the plant), as well as from several locations in the surrounding provincial forests (see Figure 1 and Figure 2). Depending on the amount of water in river basins flowing into reservoirs for hydropower, the location of the monitoring stations will be selected. Normally, rain gauges are installed at the upstream of a river or of effluent while the stations measuring water level are often installed downstream of a river to monitor its water levels and water flow rate.

In our study area, the survey for data collection is very difficult and strenuous. The topography of Borikhamxai province and areas near by Theun Hinboun hydropower consists of mostly rugged hills, rivers, mountains, which makes the transport of the survey instrumentation devices very difficult (Figure 1). Beside of surveying the most favourable sites for the measurement and evaluation, we have to examine whether the GSM operations are stable in order to provide information to the data transfer module. The given objective of the plant was to install 13 stations for GPRS-based transmission of data to the centre. For this, the survey team investigated 25 locations and among them, the 13 most suitable places were selected (Figure 2) (Open Geospatial Consortium, 2006; Steiniger et al., 2005).

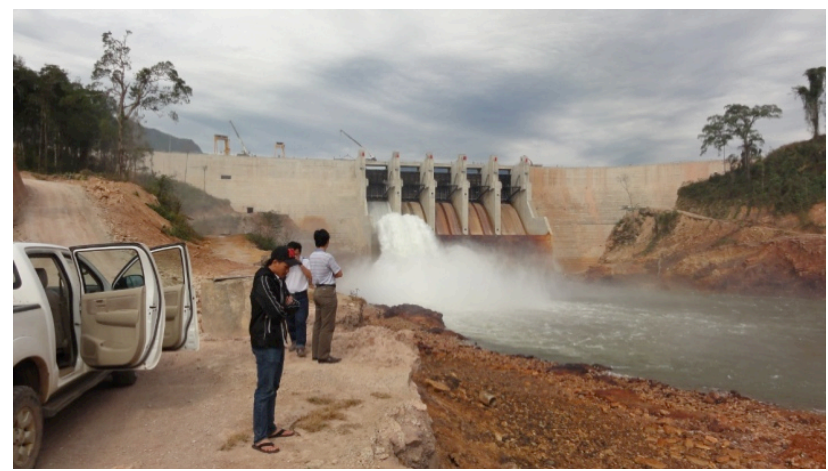

Figure 1. Survey in hydropower plant Theun Hinboun

\section{Design of the management and mon- itoring system}

\subsection{Structure of the system}

The system architecture consists of a group of measurement devices, data acquisition devices and central control room at the station. Figure 3 shows a schematic representation of the system, which has the main objective the collection of data from the measurement devices. The collected data is stored in the memory of station devices and then sent to the centre via wireless networks GSM / GPRS and Internet (Ngo et al., 2012). At the receiving station, the database management program will collect and store the measured parameters such as reservoir water level, rainfall, and some other parameters.

\subsection{Structure of devices collecting and transmitting data}

The devices used in the project include processors PIC 24F256GB106, Datalogger; module GSM SIM900 transmitting by GPRS, power supply with protection against over-voltage, against convolution source, memory card (1 
GB) and some other devices such as LED, horn etc. The power supply for the station board varies from $9 \mathrm{~V}$ DC to $36 \mathrm{~V}$ DC while the output powers of the station board are
4.2V DC and 3.3V DC. The software is built based on MPLAB IDE development system for Microchip C30 compiler Toolsuite (Figure 4).

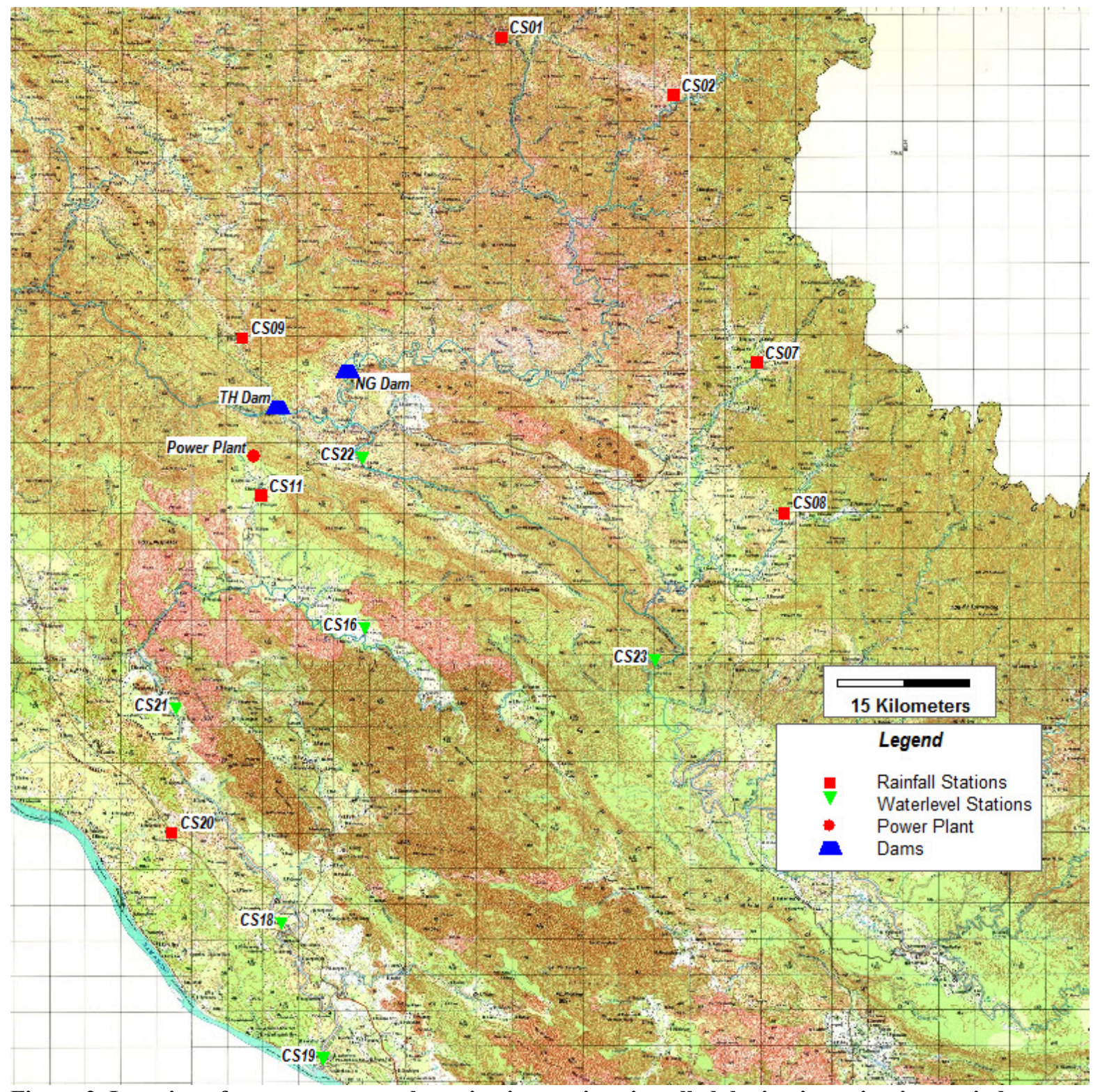

Figure 2. Location of measurement and monitoring stations installed during investigation period

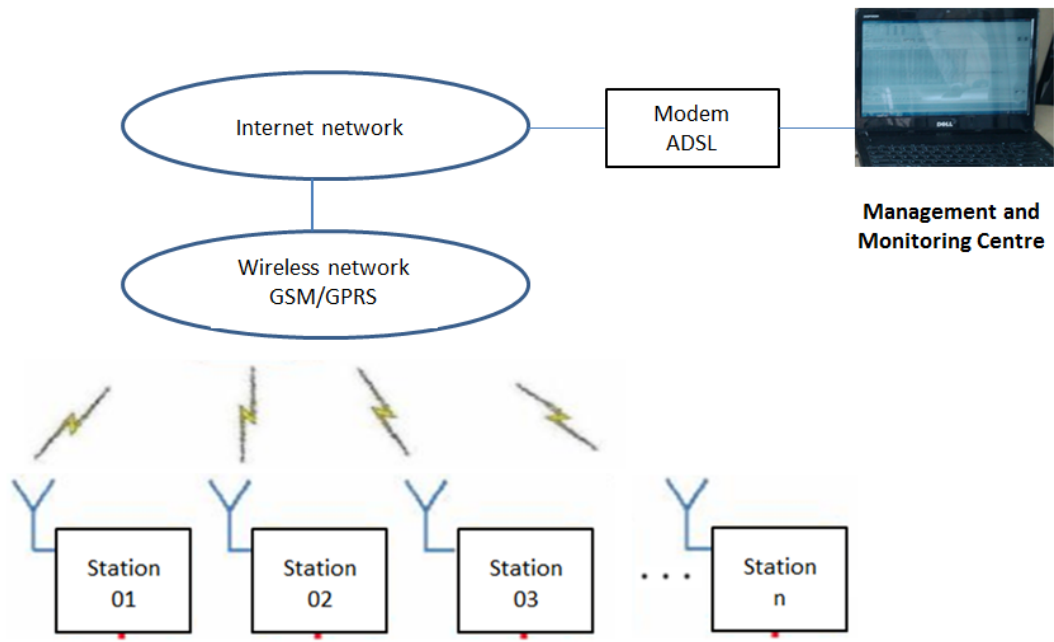

Figure 3. Structure of management and monitoring system 


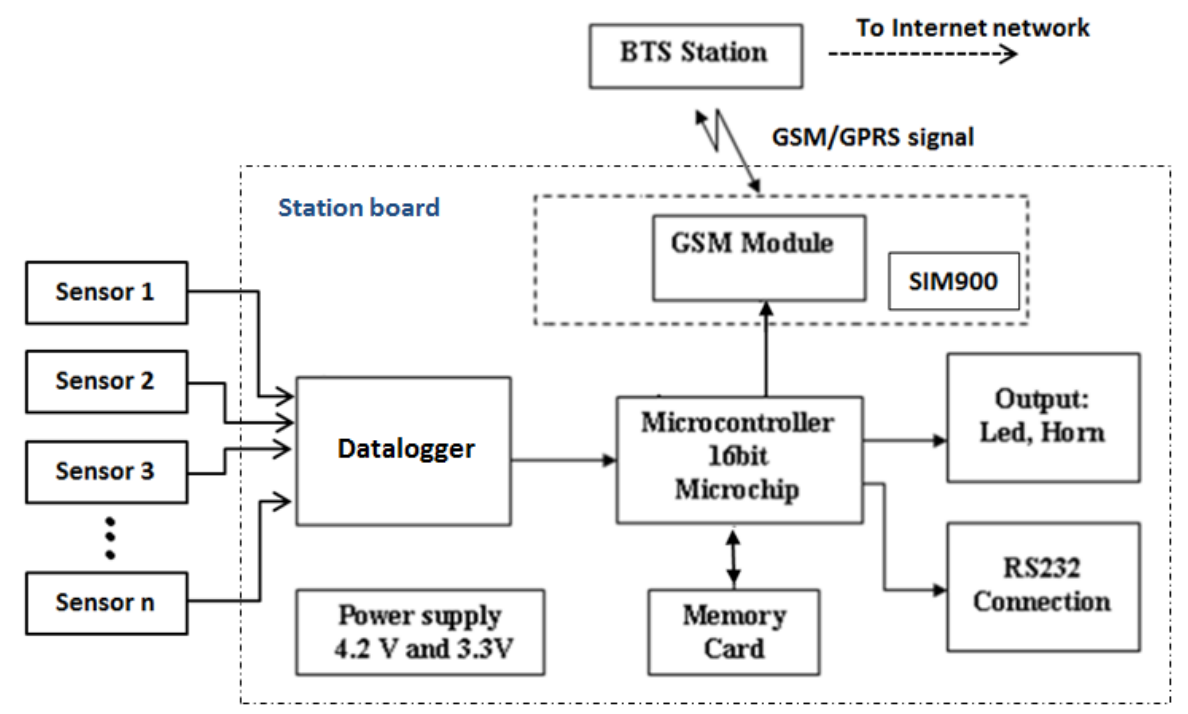

Figure 4. Block diagram of collecting device

The measuring equipment include sensors measuring rainfall, water level, wind strength, etc. The sensor VW piezometers of Slope Indicator measuring water level is of the sensor based on pressure. The probe will be submersed into the rivers or lakes. When the water level in these rivers and lakes changes, the pressure will change respectively. From that, the sensor will read the current to the respective value in the range of 4-20 mA.

The sensors TB4 and TB4MM measuring the rainfall are made by Campbell Scientific manufacturer and work on the principle of cumulative count data. When it rains, the water will fall into the hoppers and then ot will flow and pour into the gutters inside. The gutters are divided into two sides, as shown in Figure 5. When the water flows into the left gutter, due to the weight of the water, the gutter will be turned over and activate the switch underneath. After that, the water will be poured into the right gutter until this gutter is full, then the right gutter will be turned over and activate the switch underneath. The latter switch is opposite to the former switch through the axis of the gutter turning. The cycle continues to operate in that manner until the end of the rain. The heavier the rain intensity, the greater numbers of turning over the gutters during one hour. Thus, the output signal will be higher during one hour. The conversion coefficient calculated for one time of turning over of the gutter is $0.2 \mathrm{~mm}$ for the TB4MM sensor and $0.254 \mathrm{~mm}$ for the TB4 sensor, respectively. This is one digital signal given by the state transition of the switch.
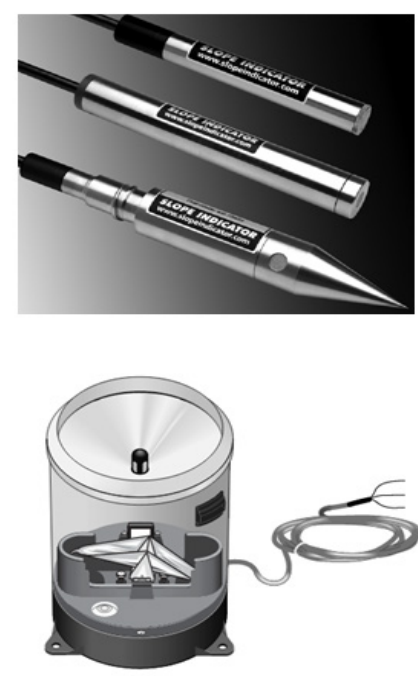

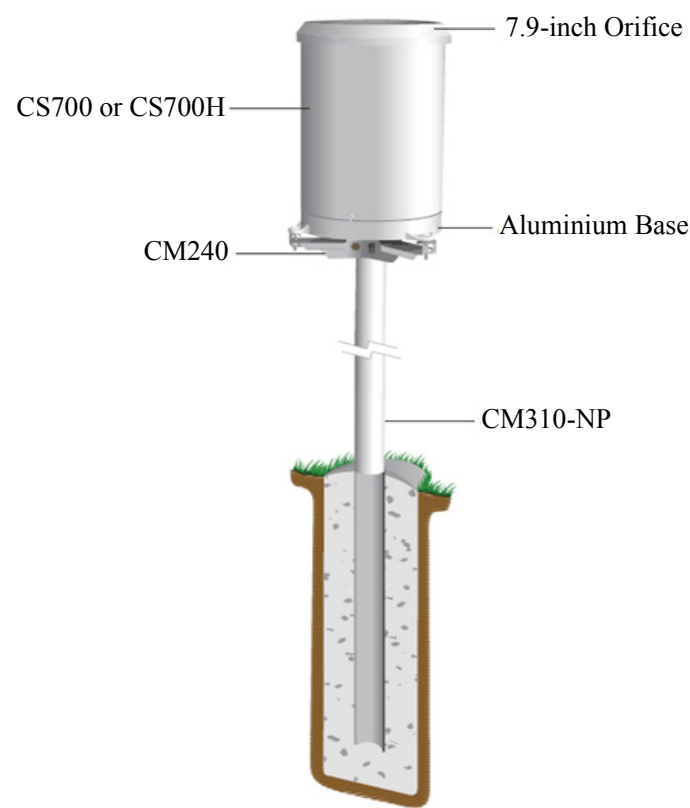

Figure 5. Sensors VW piezometers and TB4/TB4MM

These measuring devices are connected to the equipment that read signals from the sensors Datalogger CR800, CR1000, CR10X (Compbell Scientific manufacturer, see Figure 6). The data are then processed and transmitted to the microprocessor. Sampling time is different between stations (15 minutes, 30 minutes and 60 minutes). The frequency of data storage depends on the importance of individual stations. For the important station, frequency will be higher, such as $15 \mathrm{~min}$ or $30 \mathrm{~min}$, and is often applied for water level measurement stations. The fre- 
quency of all the rainfall stations according to the standard of the meteorological department is 60 min per sample (Campbell Scientific, 2012).

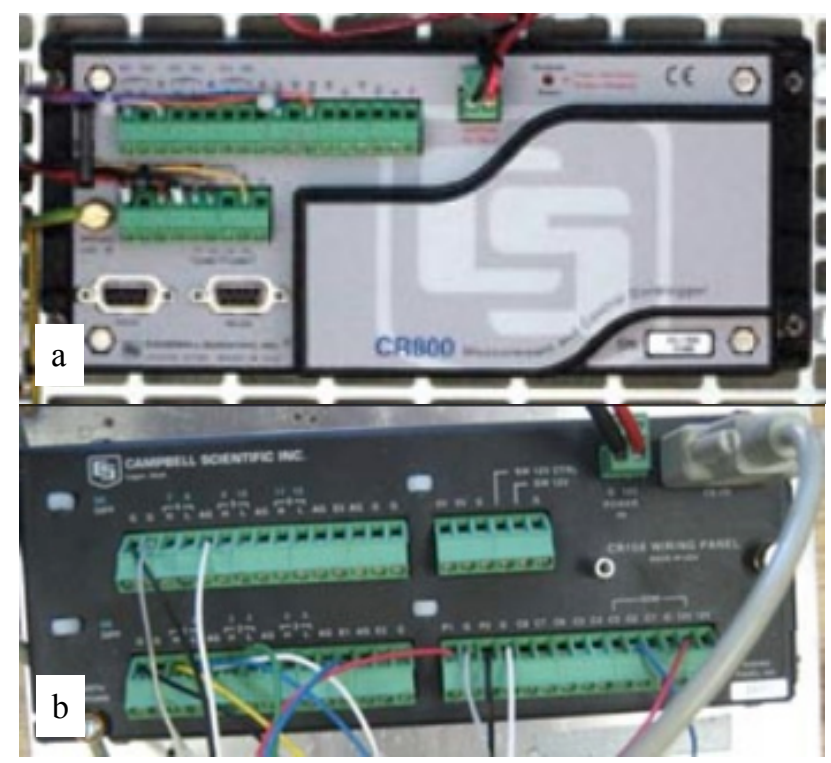

Figure 6. Dataloger CR800 (a) and Datalogger

CR1000 (b)

The module SIM900 has functions for message processing and GPRS data packet. The main microprocessor is PIC 24F256GB106. It will read, process the data, and execute the commands to control the transmission of data from the module SIM900 to the monitoring centre by GPRS connection. In the station, a measuring device transmits signals to the BTS station using GSM/GPRS. From here, the data will be pushed to internet and sent to centre by ADSL Modem.

Currently, these devices are redesigned and developed based on FPAA, using the chip AN231K04 and compatible ones of Anadigm manufacturer. This chip can use elements to configure inside it to create amplification, differentiation, and filters. From there, we can use it to read the analogue signals from sensors, then process, filter, amplify and transmit the signal to the main processor to handle and transfer the data to the server. Figure 7 shows the real device.

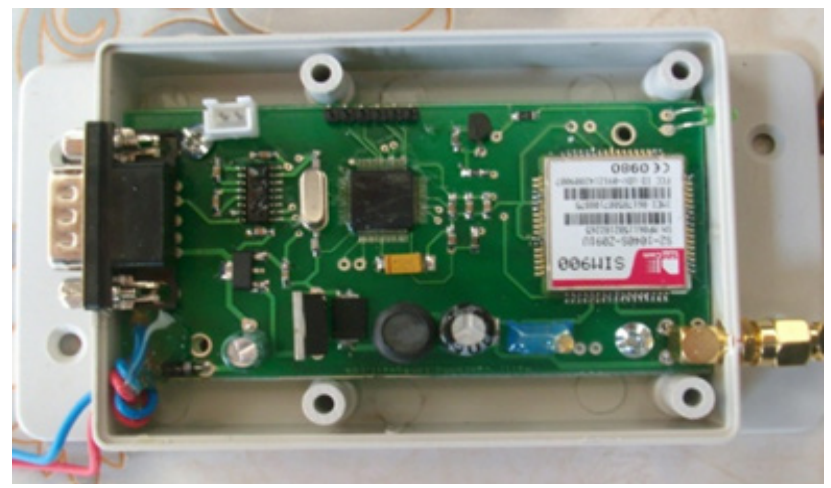

Figure 7. Our real device

There are 13 stations installed arround the hydropower plant (Figure 2): seven stations for reainfall measurement (CS01, CS02, CS07, CS08, CS09, CS11, CS20) and six stations for the measurement of water level (CS16, CS18,
CS19, CS21, CS22, CS23). The equipment located at the station is designed with features that can change the IP address and change the station name for the device.

\section{Targets of the changes:}

- Changing IP address to reset devices' address when moving to another server

- Changing ID of the station to reset devices' name or change the devices if necessary.

- Changing frequencies of sending data as well as structure of packets to the centre.

\section{Features:}

+ All of the above changes are made for using the devices in a simple way. It is not needed to rewrite the code to program the microprocessors. The performance is defined by two methods:

- Implementation by software on computer (interface). The devices will be connected to the interface via RS232 port. From this interface, the users can configure device parameters on the incoming IP address as the station ID and the frequency of sending. In addition, this interface can also check the operation status of the device.

- Implementation by SMS. The users can configure the parameters for the device with one SMS while the equipment is still operating normally. The users will compose one message based on the defined rule and send it to the phone number of the device. Then the device will automatically update the parameters and report back to the user's phone that the change has been successful or not. The purpose of this test is to know the certainty of implementation, if the change was successful or not.

+ All changes of the above parameters after configuration are saved to the flash memory in the microprocessor. Therefore, when the devices are losing power and the power comes back on, the parameters are not lost.

+ In addition, the devices also have the function of warning to landline or mobile phone by a text message when the system has a problem such as rainfall or water level exceeds a certain level, or when there is an intruder, or when the devices are stolen.

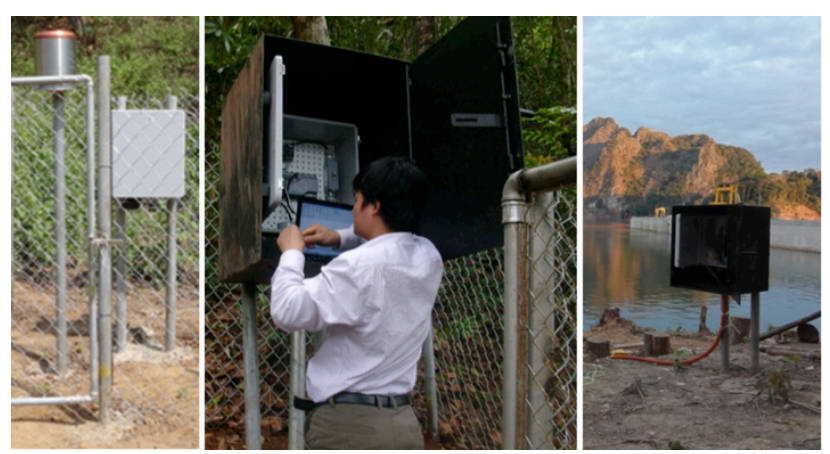

Figure 8. Mounting the device in the investigated area

\subsection{Server at the centre}

The software at the centre includes two packages. The first package connects and gets the data, and the second is the filtering distribution data analysis package.

The functions of the first software package are connection and receiving data from the sending station. It is programmed via communication TCP Socket client / server. 


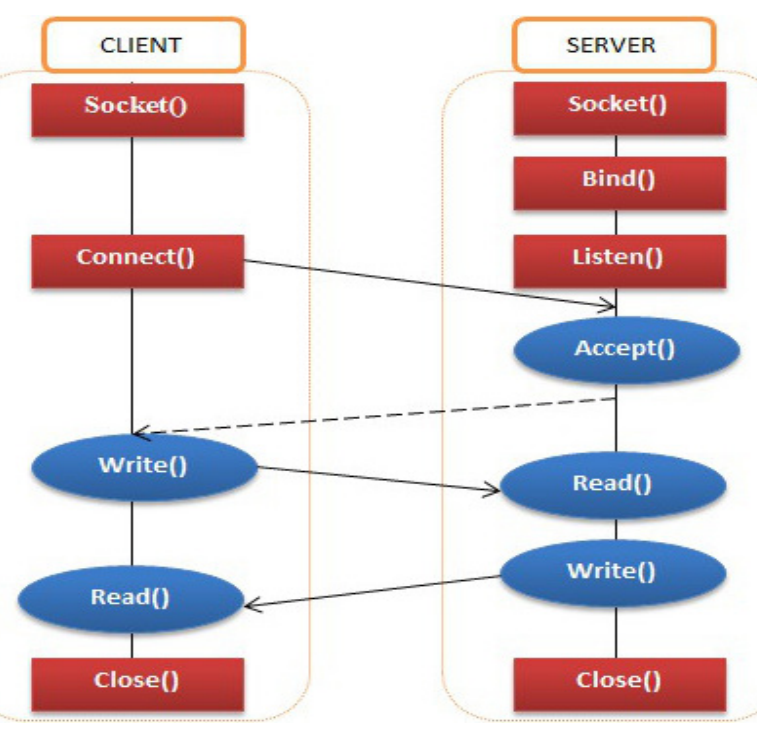

Figure 9. Algorithm diagram of software connecting and receiving data

The functions of the second software package are separating the data of different stations, analyzing, charting and storing the data. Because the system consists of many different stations at different places, these stations are indicated by different IDs. And for each station, the time of sending data is different. For the water level measuring stations the duration between each time of data transmission is 15 minutes. And for the rain gauges it can be 30 minutes or 60 minutes, depending on the importance level of each station. Consequently, this software must separate and group the different stations to display and store as well as provide statistical reports per day, month, quarter or year.

\section{Hydrology monitoring}

The gauges measuring and monitoring the rain and water level are installed at 13 different stations, among which rainfall stations are located at the upstream of the river and most of the water level stations are located at the downstream of the river. Our system focuses on the automatic collection, processing and transmition of data to the monitoring and management centre. On the other hand, the investigated parameters are measured using standard sensors, which are imported from the famous companies.

In Laos, all existing meteorological instruments in place at 48 stations are analogue, manual types. Among these, JICA Technical Cooperation Projects recently upgraded only six stations, but the devices are still analogue and not automatic (Pathoummady, 2010). In fact, the meteorological stations in Laos with analogue instruments are of potential risk for data errors induced by both low quality of instruments and reduced proficiency of observers. Since the number of meteorological stations in Laos is insufficient and their efficiency is low, the hydrological data are only measured with low accuracy at a reduced number of places. According to the Department of Meteorology and Hydrology, Water Resources and Environment Administration, Lao People's Democratic Republic, the rainfall amount measured at four stations in Laos from 1976 to 2009 varied from $1080 \mathrm{~mm}$ to $2694 \mathrm{~mm}$ with the average rainfall of $1721 \mathrm{~mm}$ (Department of Meteorology and Hydrology, 2013).

Table 1: Peak rainfall intensity measured during 72 hours at the station CS11 in 2011

Peak Rainfall Intensities

\begin{tabular}{|c|c|c|c|c|c|c|c|c|c|c|c|c|}
\hline \multirow{2}{*}{ 节 } & \multirow{2}{*}{$\begin{array}{c}2011 \\
\text { Month }\end{array}$} & \multirow{2}{*}{$\begin{array}{l}\text { Total } \\
(\mathbf{m m})\end{array}$} & \multicolumn{2}{|c|}{06 hour } & \multicolumn{2}{|c|}{12 Hour } & \multicolumn{2}{|c|}{24 Hour } & \multicolumn{2}{|c|}{48 Hour } & \multicolumn{2}{|c|}{72 Hour } \\
\hline & & & $\begin{array}{l}\text { Depth } \\
(\mathrm{mm})\end{array}$ & $\begin{array}{l}\text { Day } \\
\text { time }\end{array}$ & $\begin{array}{l}\text { Depth } \\
(\mathrm{mm})\end{array}$ & $\begin{array}{l}\text { Day } \\
\text { time }\end{array}$ & $\begin{array}{l}\text { Depth } \\
(\mathrm{mm})\end{array}$ & $\begin{array}{l}\text { Day } \\
\text { time }\end{array}$ & $\begin{array}{l}\text { Depth } \\
(\mathrm{mm})\end{array}$ & $\begin{array}{l}\text { Day } \\
\text { time }\end{array}$ & $\begin{array}{l}\text { Depth } \\
(\mathrm{mm})\end{array}$ & $\begin{array}{l}\text { Day } \\
\text { time }\end{array}$ \\
\hline \multirow{12}{*}{$\bar{\nabla}$} & Jan & 0.00 & 0.00 & $0104: 58$ & 0.00 & 01 10:58 & 0.00 & $0122: 58$ & 0.00 & $0222: 58$ & 0.00 & 03 22:58 \\
\hline & Feb & 0.20 & 0.20 & 13 07:01 & 0.20 & 13 07:01 & 0.20 & 13 07:01 & 0.20 & 13 07:01 & 0.20 & 13 07:01 \\
\hline & Mar & 39.40 & 15.60 & 08 12:00 & 17.00 & $3004: 58$ & 18.80 & $3013: 58$ & 18.80 & $3013: 58$ & 18.80 & $3013: 58$ \\
\hline & Apr & 26.80 & 22.60 & 221 & 22.60 & 2219 & 22.80 & 23 09:00 & 22.80 & 23 09:00 & 22.80 & 23 09:00 \\
\hline & May & 212.40 & 33.00 & $1422: 58$ & 55.20 & $1422: 01$ & 55.40 & $1422: 58$ & 60.40 & $1422: 58$ & 69.60 & 17 06:00 \\
\hline & Jun & 984.60 & 153.00 & 23 21:00 & 189.20 & 24 03:00 & 247.40 & $2322: 58$ & 336.00 & $2422: 58$ & 407.60 & $2519: 58$ \\
\hline & Jul & 1249.80 & 90.60 & 30 18:00 & 147.80 & $3103: 00$ & 219.00 & $3104: 58$ & 274.80 & 01 00:00 & 300.60 & $2104: 01$ \\
\hline & Aug & 843.00 & 100.40 & $0904: 58$ & 124.00 & 02 12:00 & 153.40 & 02 22:01 & 257.40 & 09 10:58 & 282.00 & 09 10:58 \\
\hline & Sep & 778.00 & 146.80 & $0100: 00$ & 191.20 & 01 00:00 & 191.40 & $0100: 00$ & 194.20 & 01 00:00 & 197.20 & 01 00:00 \\
\hline & Oct & 74.00 & 28.40 & 02 07:58 & 29.60 & 02 07:58 & 44.40 & 02 07:58 & 55.20 & 03 00:00 & 55.20 & 04 00:00 \\
\hline & Nov & 0.00 & 0.00 & 01 06:00 & 0.00 & 01 12:00 & 0.00 & 02 00:00 & 0.00 & 03 00:00 & 0.00 & 04 00:00 \\
\hline & Dec & 0.00 & 0.00 & 01 06:00 & 0.00 & 01 12:00 & 0.00 & 02 00:00 & 0.00 & 03 00:00 & 0.00 & 04 00:00 \\
\hline
\end{tabular}

For the purpose of this paper, we do not aim at comparing the hydrological data measured by our system with the data from the Department of Meteorology and Hydrology of Laos. Instead, we just focus on the point that the recorded data are automatically transmitted to the central station. Then the data can be extracted from the database management program at any time and expressed automatically under different performance types such as in table, diagram or graph.

In our investigation, the data in Table 1 and Table 2 depict an example of rainfall intensities measured over a 
shorter period of 72 hours. In this case, one can observe the fine resolution of the data collected, impossible otherwise if the readings were to be done manually, by human operators. The recorded data include the realtime of measurement, every six hours. These tables also indicate the total monthly amount of rainfall measured in 2011 at two stations, CS11 and CS20. From these data, we can calculate that the total rainfall amount in 2011 at the stations CS11 and CS20 (around Theun Hinboun hydropower plant in Borikhamxai province) is $4208 \mathrm{~mm}$ and 2579 $\mathrm{mm}$, respectively.
In our project, as explained above, the sampling time could be every 15 minutes, 30 minutes and 60 minutes. For the water level measurement stations which are important stations, frequency of storing data is 15 minutes or 30 minutes. Frequency of all the rainfall stations is 60 minutes per sample according to the standard of the meteorological department.

Table 2: Peak rainfall intensity measured during 72 hours at the station CS20 in 2011

Peak Rainfall Intensities

\begin{tabular}{|c|c|c|c|c|c|c|c|c|c|c|c|c|}
\hline \multirow{3}{*}{ 苛 } & \multirow{3}{*}{$\begin{array}{c}2011 \\
\text { Month }\end{array}$} & \multirow{3}{*}{$\begin{array}{l}\text { Total } \\
(\mathbf{m m})\end{array}$} & \multirow{2}{*}{\multicolumn{2}{|c|}{06 hour }} & \multirow{2}{*}{\multicolumn{2}{|c|}{12 Hour }} & \multirow{2}{*}{\multicolumn{2}{|c|}{24 Hour }} & & & \multirow{2}{*}{\multicolumn{2}{|c|}{72 Hour }} \\
\hline & & & & & & & & & \multicolumn{2}{|c|}{48 Hour } & & \\
\hline & & & $\begin{array}{l}\text { Depth } \\
(\mathrm{mm})\end{array}$ & $\begin{array}{l}\text { Day } \\
\text { time }\end{array}$ & $\begin{array}{r}\text { Depth } \\
\text { (mm) }\end{array}$ & $\begin{array}{l}\text { Day } \\
\text { time }\end{array}$ & $\begin{array}{l}\text { Depth } \\
(\mathbf{m m})\end{array}$ & $\begin{array}{l}\text { Day } \\
\text { time }\end{array}$ & $\begin{array}{l}\text { Depth } \\
(\mathrm{mm})\end{array}$ & $\begin{array}{l}\text { Day } \\
\text { time }\end{array}$ & $\begin{array}{l}\text { Depth } \\
(\mathbf{m m})\end{array}$ & $\begin{array}{l}\text { Day } \\
\text { time }\end{array}$ \\
\hline \multirow{12}{*}{$\begin{array}{l}\text { ָิ } \\
\text { రి }\end{array}$} & Jan & .00 & .00 & 1 04:58 & 0.00 & $10: 58$ & 0.00 & $0122: 58$ & 0.00 & 02 22:58 & 0.00 & $0322: 58$ \\
\hline & Feb & 0.20 & 0.20 & $1316: 58$ & 0.20 & $1316: 58$ & 0.20 & 13 16:58 & 0.20 & 13 16:58 & 0.20 & $1316: 58$ \\
\hline & Mar & 19.40 & 7.00 & $3001: 58$ & 10.80 & $3007: 58$ & 14.00 & $3010: 58$ & 14.00 & $3010: 58$ & 14.00 & $3010: 58$ \\
\hline & Apr & 56.20 & 15.40 & $2219: 58$ & 15.40 & $2219: 58$ & 16.20 & $2816: 58$ & 23.80 & $2816: 58$ & 30.60 & $2913: 01$ \\
\hline & May & 170.00 & 28.00 & 1015.00 & 20.00 & $1813: 58$ & 40.00 & 1310.01 & 46.60 & $1813: 58$ & 62.00 & $1922: 58$ \\
\hline & Jun & 350.20 & 40.00 & $2513: 01$ & 49.00 & $2513: 01$ & 69.00 & $2512: 00$ & 118.80 & 25 19:01 & 126.40 & $2615: 00$ \\
\hline & Jul & 795.60 & 118.00 & $3019: 58$ & 160.80 & $3101: 58$ & 270.20 & $3103: 00$ & 310.60 & 31 18:00 & 318.00 & 01 00:00 \\
\hline & Aug & 513.40 & 72.20 & 02 09:00 & 81.80 & 02 13:58 & 118.40 & 02 10:58 & 192.00 & 03 13:01 & 212.40 & 04 00:00 \\
\hline & Sep & 591.80 & 108.40 & $1604: 01$ & 113.80 & $1607: 58$ & 150.00 & $1607: 01$ & 238.00 & $1704: 58$ & 286.20 & 17 04:58 \\
\hline & Oct & 76.00 & 61.60 & 01 06:00 & 63.20 & 01 12:00 & 64.20 & 02 00:00 & 68.40 & 03 00:00 & 68.40 & 04 00:00 \\
\hline & Nov & 0.00 & 0.00 & 01 06:00 & 0.00 & 01 12:00 & 0.00 & 02 00:00 & 0.00 & 03 00:00 & 0.00 & 04 00:00 \\
\hline & Dec & 0.00 & 0.00 & 01 06:00 & 0.00 & 01 12:00 & 0.00 & 02 00:00 & 0.00 & 03 00:00 & 0.00 & 04 00:00 \\
\hline
\end{tabular}

The collected data can be processed and interpreted using the automatic system. All the data were automatically collected and transmitted to the central station in real time allowing statistical analysis and performance under the different formats such as table, diagram or graphic. Figure 10 and Figure 11 show the monthly rainfall distribution measured at station CS11 and station CS20 in 2011.

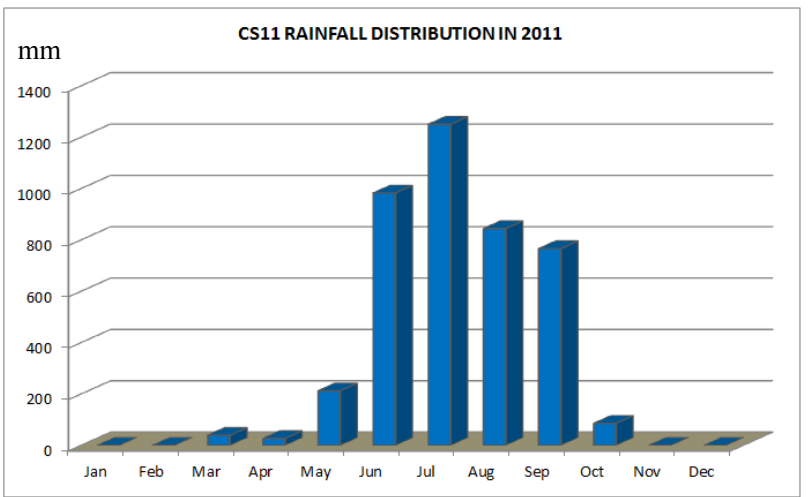

Figure 10. Rainfall distribution measured at station CS11 in 2011

By interpretation under these diagrams, it is easier to see that rainy season lasts from April/May to September/October, and the highest precipitation amount was measured at both mentioned stations in July, which were $1250 \mathrm{~mm}$ and $796 \mathrm{~mm}$ at CS11 and CS20, respectively.

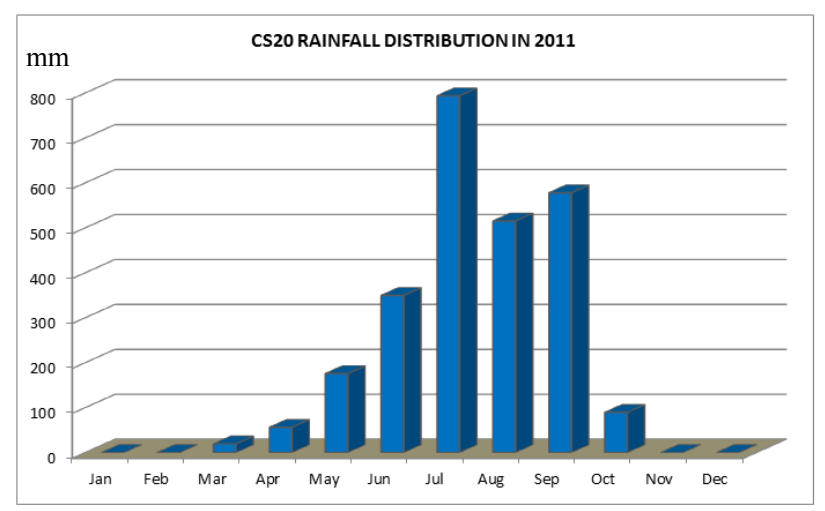

Figure 11. Rainfall distribution measured at station CS20 in 2011

Our devices can automatically measure and record the rainfall intensities at the investigated stations and transmit the recorded data to the centre. However, in this project, we emphasize on transmission of the recorded data to the central station for easier management and monitoring. We can check the results whenever for any period of time easily i.e. the data can be extracted per hour, week, month, etc. For instance, we can visualize the daily rainfall amount during August 2012 measured at station CS09 (Figure 12): 


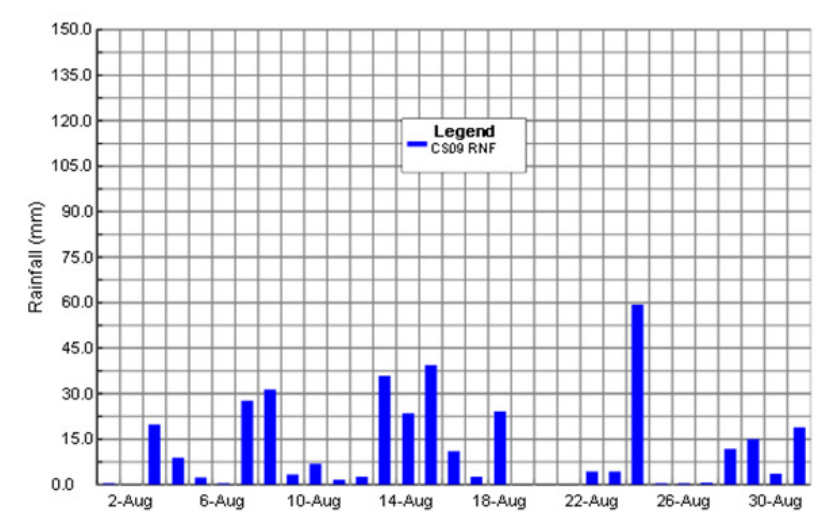

Figure 12. Daily rainfall at CS09 during August 2012
Data about water level monitoring at some stations (CS16, CS21, CS18, CS19 top to bottom) during August 2012 are shown as graphic in Figure 13. The water surface elevation varies from $141 \mathrm{~m}$ to $158 \mathrm{~m}$ and the order of deep level at the stations is as following: CS16 $>$ CS21 $>$ CS $18>$ CS 19 .

The data collected for 13 stations in 2011 and 2012 in our project are extremely valuable for Laos since the national meteorological network, the observations and the data management in Lao PDR are ineffective. Most of instruments in the monitoring network are aged and some are deteriorated (Pathoummady, 2010).

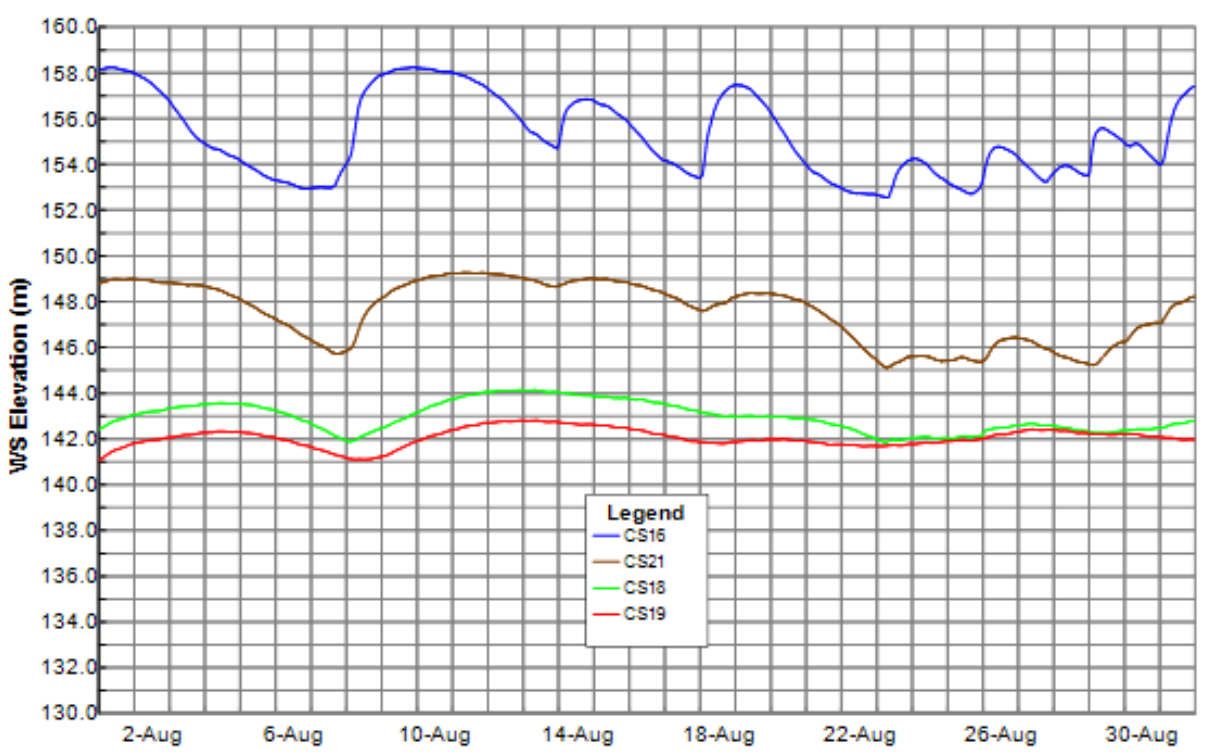

Figure 13. One screen of data monitoring of water surface elevation during August 2012

\section{Conclusion}

New design and implementation of measurement devices by local means are important for the development of monitoring systems at hydropower plants in Vietnam and other countries in the region. The device system has solved the problem of automation for the statistic purposes while the equipment designed ensures high reliability.

The automatical measurement of essential parameters of the hydropower plants by such device systems is needed in Laos and Vietnam. The application of remote data transmission via GPRS services has brought in economic efficiency in terms of system requirements as well as features of direct monitoring and prompt handling situations when problems occur.

Concurrently, new technology applications will cause the system to become more compact, fully integrated on a motherboard. By design and creation of this automatic system, we achieve an enormous benefit in terms of manpower and time since data can be transmitted accurately by GPRS instead of manual reading and reporting.

After several investigation and test phases, the official installation of devices was done in March 2012. After this date, the devices have been active $24 / 24$ and no problem occurred. Since the system went into operation, the hy- dropower plant has been operating in a more effective manner in regulating water resources as well as the capacity of the plant so that the most efficient operation was achieved.

The automatic hydrological monitoring system in the Theun Hinboun hydropower plant, Na Hin village, Borikhamxai province, Lao People's Democratic Republic has proven to be stable and efficient. It could therefore be extended and implemented at different other locations in Laos and surrounding countries where meteorological data is still collected and transmitted manually.

\section{References}

[1] Campbell Scientific, Inc. 2012. CR1000 measurement and control system - A rugged instrument with research-grade performance

[2] Department of Meteorology and Hydrology, Water Resources and Environment Administration, Lao People's Democratic Republic (http://www.nsc.gov.la/Statistics/Selected\%20Statist ics/Meteorology.htm), retrieved on 8-20-2013.

[3] Environment Monitoring Centre 2012. The overall monitoring program on environmental impact of hydropower operations in the Central Highlands region for the phase $2013-2017,41 \mathrm{pp}$. 
[4] Han, K., Zhang, D., Bo, J., Zhang, Z. 2012. Hydrological monitoring system design and implementation based on IOT. Physics Procedia 33: 449-454

[5] Ngo, T.B., Nguyen, T.A., Vu, N.Q., Chu, T.T.H., Cao, M.Q. 2012. Management and monitoring of air and water pollution by using GIS technology. Journal of Vietnamese Environment 3(1): 50-54

[6] Open Geospatial Consortium, Inc. 2006. OpenGIS ${ }^{\circledR}$ Web Map Server Implementation Specification, http://www.opengeospatial.org

[7] Pathoummady, S. 2010. Status of Meteorological Network, Observations and Data Management in Lao PDR. JMA/WMO Workshop on quality management in surface, climate and upper-air observations in ra II (Asia) Tokyo, Japan, 27-30 July 2010

[8] Steiniger, S., Neun, M., Edwardes, A. 2005. Foundations of Location Based Services, CartouCHel Lecture Notes on LBS, V. 1.0 